Comparative Population Studies

Vol. 43 (2018): 99-130 (Date of release: 31.10.2018)

\title{
The Two-Part Gender Revolution, Women's Second Shift and Changing Cohort Fertility
}

\author{
Tomas Frejka, Frances Goldscheider, Trude Lappegård
}

\begin{abstract}
The two parts of the gender revolution have been evolving side by side at least since the 1960s. The first part, women's entry into the public sphere, proceeded faster than the second part, men's entry into the private sphere. Consequently, many employed mothers have carried a greater burden of paid and unpaid family support than fathers throughout the second half of the $20^{\text {th }}$ century. This constituted women's "second shift," depressing fertility. A central focus of this paper is to establish second shift trends during the second half of the $20^{\text {th }}$ century and their effects on fertility. Our analyses are based on data on cohort fertility, male and female labor force participation, and male and female domestic hours worked from 11 countries in Northern Europe, Western/central Europe, Southern Europe, and North America between 1960/70 and 2000/2014. We find that the gender revolution had not generated a turnaround, i.e. an increase in cohort fertility, by the end of the $20^{\text {th }}$ century. Nevertheless, wherever the gender revolution has made progress in reducing women's second shift, cohort fertility declined the least; where the second shift is large and/or has not been reduced, cohort fertility has declined the most.
\end{abstract}

Keywords: Two-part gender revolution - Transformation of male breadwinner family model $\cdot$ Women in public sphere $\cdot$ Men in private sphere $\cdot$ Women's second shift

\section{Introduction}

The on-going transformation of the male breadwinner family model has been among the most remarkable societal changes of the past 50 to 60 years. This appears to be occurring in two parts: The first part, the growth of female labor force participation, is accompanied by a second part, the growth in men's involvement in the tasks at home. These overlapping parts are, in essence, the gender revolution (Goldscheider et al. 2015). 
This revolution has not been without consequences. The first part has evidently been unbalancing the family, reducing fertility and disrupting unions as men and women have struggled with women's new roles that combine responsibilities in both the public sphere of employment and the private sphere of the family (Cherlin 2016; Rindfuss/Choe 2015, 2016; Arpino et al. 2015; Lesthaeghe 2010; Sobotka et al. 2011a; Frejka et al. 2008; Olah/Bernhardt 2008; Engelhart et al. 2004; Brewster/ Rindfuss 2000; Hochschild/Machung 1989; Lesthaeghe/van de Kaa 1986). The second part might be rebalancing the family, as men's increased domestic involvement reduces the pressure on women, perhaps stabilizing unions and creating the potential for fertility to increase (Anderson/Kohler 2015; Esping-Andersen/Billari 2015; Goldscheider et al. 2015). The size and duration of the gap between the two stages, which has been called women's "second shift" (Hochschild/Machung 1989), in which women attempt to meet both work and major home obligations with relatively unimportant involvement of their partners, may thus be very consequential for fertility and family stability.

Two early analyses of this proposition vis-à-vis fertility thus far did not find fertility turnarounds or reversals (Frejka et al. 2016a/b). However, that research focused on the second half of the gender revolution - the increase in men's involvement in household tasks - and did not examine either the effects of the first half of the gender revolution or those of the gap between the two halves, both of which have varied across countries and over time. This means that it is important to consider, as well, the on-going fertility depressing effects of the first half, as female labor force participation increased, particularly in countries that provide little support to reduce work-family conflict, such as high quality childcare and job-protected, paid family leave. It is also important to consider the relationship between these two trends and the extent to which their trajectories open up larger or smaller "second shifts," i.e., to what extent an increase in women's employment is or is not balanced by increases in men's domestic contributions. In this paper, we examine the fertility of women born in different birth cohorts, who belong to different generations where fertility decisions have been made within different gender revolution contexts. Hence, this paper will examine the connections between these two trends - the growth of female labor force participation relative to men's and the growth in men's domestic participation relative to women's - and their relationships with cohort fertility across a wide range of industrialized countries. We ask: Do countries with patterns that minimize the "second shift" experience less drastic declines or even increases in fertility than those seen in countries whose patterns maximize the second shift? The minimizing of the second shift is generated by an increase in men's domestic share offsetting increases in female labor force participation. Our focus is on the impact on fertility of these two parts of the gender revolution, although we will also consider whether state policies that provide support to parents, such as subsidized high quality childcare and paid parental leave, might also help maintain fertility. 


\section{Background: Gender Role Change and Fertility}

Our analysis of cohort fertility change rests on the theoretical perspective that there are two halves of the gender revolution. The first half is women's increased involvement in the public sphere, predominantly by massively increasing their labor force participation; the second half is men's increased involvement in the tasks of home and family. While they are related, in that women's employment encourages men's increased involvement in the home (Evertsson 2014), the prevalence of women's "second shift" suggests that the relationship is a weak one; men do not respond fully to women's need for help in the domestic sphere and many women initially did not want them to (Goldscheider et al. 2015). Hence, they need to be thought about separately.

The first half of the gender revolution had major consequences for families as women first took on employment that could be fit around a life of family care and then increasingly began to plan for employment as a major adult role (Goldin 2006). Women delayed family formation as they increased their human capital in order to make employment more financially rewarding and they decreased the numbers of children they planned to have and actually had in order to reduce work-family conflict (Macunovich 1996). In the process, unions became more unstable. This produced the package of family changes known as "the Second Demographic Transition" (SDT), delays in union formation and childbearing, the weakening of unions with the growth in cohabitation and union dissolution, increased child bearing and raising outside stable unions, and above all, massive fertility decline (cf. Lesthaeghe 2010; Lesthaeghe/van de Kaa 1986), reaching far below replacement fertility levels in many countries. Beginning with the 1980s, many studies were undertaken to examine this set of what are often seen as problematic family changes, particularly low fertility.

In contrast, during this period the progress and potentially family-friendly consequences of the second half of the gender revolution were largely ignored. However, they have recently attracted considerable attention in a number of papers (e.g., Cherlin 2016; Anderson/Kohler 2015; Esping-Andersen/Billari 2015; Goldscheider et al. 2015). "[A]...return to 'more family' as gender egalitarianism gains increasingly dominant normative status" (Esping-Andersen/Billari 2015: 3) is a common theme elaborated in these papers. The authors argue that the second half of the gender revolution has the potential for raising the prevalence of marriages, diminishing the frequency of divorces, and, the focus of this analysis, raising fertility, trends that perhaps are already underway. Goldscheider et al. (2015: 229) have proposed that “... men's increased involvement in the home, the second half of the gender revolution ... has the promise of increasing both fertility and the proportions entering and remaining in committed unions."

Although taking other theoretical perspectives, primarily that of SDT analysts (e.g., Lesthaeghe 2010), there is an extensive literature linking gender role change and fertility change, on which we build. Research has examined different aspects of gender role change and different aspects of fertility, and has been conducted at different levels of analysis, focusing either on relationships at the individual level 
or on differences among countries or other geographic/legal units. Gender role change has been studied in terms of both behavior (e.g., Cooke 2009) and attitudes (e.g., Brinton/Lee 2016), as well as in terms of country-level gender characteristics (e.g., Mills 2010). Vis-à-vis fertility, for the individual level, scholars have studied the transition to parenthood (e.g., Bernhardt/Goldscheider 2006) as well as parity progression (e.g., Dommermuth et al. 2017; Goldscheider et al. 2013; Fiori 2011; Brodmann et al. 2007; Cooke 2009). At the macro level, similarly, although most studies examine the period total fertility rate, which is a cross-sectional measure (cf. Rindfuss/Choe 2015, 2016), a few others have looked at cohort fertility (e.g., Frejka et al. 2016a/b).

In this review, we will focus primarily on macro studies, and on actual behavior rather than attitudes. We distinguish between the gendered behaviors of women and men by considering not only trends in women's role in the public sphere (female labor force participation) and in men's roles in domestic activities relating to home and children, but also the gap between trends in these two phenomena (women's second shift). Importantly, although many have studied the effects of the growth of female labor force participation, few examine the fertility consequences of the second half of the gender revolution, much less the weight of women's second shift.

\subsection{Female labor force participation and fertility}

Prior to the middle of the $20^{\text {th }}$ century, few married women worked outside the home, at least in Sweden and among the white majority in the United States, two countries recognized as leaders in the growth of female labor force participation (Stanfors/Goldscheider 2017). The late nineteenth century and the first half of the twentieth century were the period of the "separate spheres," when married women remained in the home if at all possible, even as the growth in industrial and commercial jobs drew men away from the subsistence household economy. During this period women pursued many productive roles, including replacing their husbands' chores (e.g., drawing water, maintaining kitchen gardens), in addition to their own (e.g., spinning, sewing, washing), together with increased responsibilities for the daily activities of children. These roles evolved over time, and generally became less onerous, with the growth of cities, together with the spread of running water and electrification and children's education (Cowan 1983). Nevertheless, preconditions for eventual employment roles were developing, as women's education increased, as well as their employment experience prior to marriage (Stanfors/Goldscheider 2017; Goldin 1990).

The growth of labor force participation by women during the second half of the $20^{\text {th }}$ century, especially by married women and even married mothers, as a result, was rapid. This trend has been frequently documented (Pott-Buter 1993; Rosenfeld 1996; Spain/Bianchi 1996). In the early years of the increase in female labor force participation, a research consensus emerged that it was the result of the growth in demand for "female" workers (Oppenheimer 1970; Goldin 1990). More recent studies have highlighted the positive effects of subsidized childcare (e.g., Pettit/Hook 2005). 
The negative impact of increasing female labor force participation on fertility was widely recognized from the beginning of the surge in the employment of married women (e.g., Stycos/Weller 1967). There is clearly a two-way relationship: women in couples that for whatever reason have few children are more likely to be employed, and women who plan substantial labor force engagement expect fewer children (Waite/Stolzenberg 1976). Empirical evidence confirms that the dominant causal arrow is from (plans for) employment to (plans for) childbearing, as a second income has become increasingly important for couples since the 1980s (Oppenheimer 1974).

It is also possible that the consequences of the growth in female labor force participation have changed (Matysiak/Vignoli 2008). For instance, in response to this negative impact on fertility, many countries enacted policies that have attempted to alleviate the work-fertility dilemma, such as paid parental leave and expanded, subsidized high quality childcare (Thévenon/Gauthier 2011; Gauthier 2010). But more universally, as employment changed from an occasional or emergency role for women into one that most women (and men) expect to be life-long, there was apparently a massive change in the relationship between female labor force participation and fertility, at least using cross-sectional measures of fertility and country-level data. This appears to have occurred between the 1970s and 1990s. Some studies documented a shift from the expected negative relationship to a positive relationship, at least in the cross-section, using period total fertility rates ( $A h n /$ Mira 2002; Brewster/Rindfuss 2000); another study using different data and methods found the negative relationship had attenuated to no relationship (Engelhardt et al. 2004). Others have found a U-shaped relationship, with a negative impact on fertility of attitudes favorable to female labor force participation early in the period of rapid growth followed by a positive impact (Arpino et al. 2015). It is clear that this relationship needs further exploration.

McDonald (2000) argues that the strong family-friendly policies in Northern Europe reduce the conflict between women's work and family roles. By providing some combination of excellent childcare and job-protected family leave, women can maintain a strong connection to the labor force and have several children. (This also relieves pressure on their spouses to increase their domestic responsibilities).

There is a substantial consensus in cross-national studies that the provision of high-quality, subsidized childcare supports fertility. An examination of 16 European countries finds that the most consistent positive effect on fertility is the level of childcare coverage (Baizan et al. 2016). A more limited study comparing Denmark and Spain also cites Danish childcare support as an important source of the fertility difference between these two countries (Brodmann et al. 2007). A study of Canada (Beaujot et al. 2013), which now has very different family policies in Quebec and the rest of Canada, finds that childcare has helped Quebec experience a stronger recovery from low fertility than was the case in the rest of Canada. Detailed studies of Nordic countries also agree that their childcare programs have helped them maintain fertility (e.g., Olah/Bernhardt 2008; Rindfuss et al. 2010), although some are concerned that public policies alone might not be able to sustain fertility in the longer run (Ronsen/Skrede 2010). 
Unfortunately, this package of policies is rare (OECD 2018). Hence, others (e.g., Goldscheider et al. 2015) argue that fathers' increased involvement in caring for their children is necessary to reduce women's work-family conflict (while intensifying men's, although normally to a lesser extent), enabling couples to have the numbers of children they want. Does men's home involvement support fertility?

\subsection{Men's domestic involvement and fertility}

The growth in men's involvement in the home is much less well documented than the growth of female labor force participation. This is in part because information on domestic activities has been much less regularly collected than labor force information. Labor force data became increasingly available after 1940 (Durand 1968, 1948); data on hours spent on unpaid productive work did not become even sporadically available until decades later (Marini/Shelton 1993).

Further, studies of men's involvement in housework and with their children are occurring in different disciplines. Demographers, sociologists, and economists study time use, distinguishing various household chores, of which "care" is one of many (e.g., Hook 2006; Kan et al. 2011). Social psychologists study "father involvement" focusing on accessibility, warmth, responsibility, engagement, monitoring/ control and rules for behavior, with little if any concern about time (Hofferth/Goldscheider 2015). Most time use studies seem primarily concerned with how much less housework men do than women, and most recently, on "stalls" in such positive trajectories as can be discerned (e.g., England 2010, but see Stanfors/Goldscheider 2017). In contrast, the fatherhood literature is almost uniformly positive, finding increases in father involvement on most dimensions, particularly among the more educated (Hofferth/Goldscheider 2015; Sullivan 2010), a clearly pro-family trend.

Although studies of men's and women's employment in the public sphere of work focus almost entirely on actual behavior ("participation"), much of the work on the private sphere relies on measures of attitudes (likely as a result of the relative scarcity of data), which can give very confusing results. For example, although more educated men report more egalitarian attitudes towards men's involvement in the home and with children than the less educated, some research suggests that it is less educated men who are more actively engaged in childcare than the more educated (Shows/Gerste/ 2008). Further, the effects of various attitudes and behaviors often depend on each other. Goldscheider et al. (2013) found that Swedish couples least likely to transition to a second birth were those in which the women had premotherhood attitudes that favored an egalitarian arrangement but were experiencing a traditional work-family balance.

Moving the focus to attitudes also complicates measurement issues, as the range of attitudes that have been used in studies is great. There is a tendency to broaden the analysis to "gender role attitudes," mixing attitudes towards gender differentiation in public sphere behavior with those on private sphere behavior, with often quite different results (people, and particularly men, are much more positive about women's employment than men's housework), and other determinants can also be quite different. Westoff/Higgins (2009) found that gender role attitudes had 
a negative effect on fertility while Puur et al. (2008) found a positive effect, a contradiction that was resolved by focusing on the very different measures of gender role attitudes that were employed in the two studies (Goldscheider et al. 2010).

But is this trend in male behavior vis-à-vis the second half of the gender revolution enough to have a positive impact on fertility? In particular, will it be enough to offset the negative effects of the first half of the gender revolution? Are there nascent characteristics of fertility trends that validate the hypothesis of increasing childbearing in countries in which the gender revolution is most advanced? In the international comparative analysis that follows, the fertility of countries more advanced on one or both halves of the gender revolution is compared with the fertility of a range of countries that have made less progress.

In this paper, we will focus only on the implications of the gender revolution for cohort fertility; much more work needs to be done on its impacts on union formation, dissolution and timing and on out-of-union childbearing and child rearing (see the review in Goldscheider et al. 2015). First, after reviewing trends in cohort fertility, we will document the progress of both halves of the gender revolution for 11 industrialized countries in Europe and North America. Second, we will explore whether there are characteristics of fertility trends that support the hypothesis of decreasing fertility linked with the increase in the growth of female labor force participation, and increasing childbearing in periods and places in which the second half of the gender revolution is most advanced.

\section{Data, Measures, and Methods}

\subsection{Data}

In order to analyze the relationship between cohort fertility trends and the two halves of the gender revolution, we use data from three major sources: national information on cohort fertility and labor force participation, which is often available annually; and surveys of time use from various sources, which are collected in many countries (but much more sporadically). Based on the availability of at least some data on each of these measures, we were able to analyze trends between approximately 1960 and 2010 for 11 industrialized countries: the Northern European countries of Finland, Norway, and Sweden; the Western/central European countries of France, Germany, the Netherlands, and the United Kingdom; the two English-speaking countries of North America, Canada and the United States; and two Southern European countries, Italy and Spain.

\subsection{Measures}

\subsubsection{Cohort fertility}

In this analysis we will employ the cohort total fertility rate as our ultimate dependent variable, covering the fertility of cohorts born starting in 1920. The cohort total 
fertility rate at age 40 (CTFR 40) is used instead of the actual CTFR at the end of the reproductive period at age 50 . The considerable benefit of using the CTFR 40 is that it allows us to follow cohort fertility for ten additional cohorts. This is justified by the fact that only small amounts of childbearing occur when women are in their $40 \mathrm{~s}$ 0.6-2.6 percent in the 1940s-1950s birth cohorts in the countries analyzed in this article - although these shares will be increasing in future cohorts. More importantly, the concern is focused mainly on the CTFR trends and these are almost identical at ages 40 and 50 (HFD 2018).

Information on cohort total fertility rates (CTFR) was obtained from the Human Fertility Database (HFD 2018), a joint project of the Max Planck Institute for Demographic Research and the Vienna Institute of Demography. The more commonly used measure, the period total fertility rate (PTFR), reflects not only changes in the quantum of fertility but also changes in the timing of childbearing (Frejka 2011; Sobotka et al. 2011a; Bongaarts/Feeney 1998). A PTFR decline might be the result of a decline in the quantum of fertility modified by later childbearing as, for instance, during the world-wide economic crisis late in the first decade of the $21^{\text {st }}$ century across all the countries of Europe (Comoli 2017; Sobotka et al. 2011b), while a PTFR increase might be caused by earlier childbearing or by a slowing down of childbearing postponement due to an economic recovery. In contrast to the PTFR, cohort total fertility rate trends (CTFRs) are a true expression of trends in fertility quantum (Frejka 2011; Sobotka et al. 2011a; Bongaarts/Feeney 1998).

Cohort measures in demography can be identified by the date of birth, a rule we follow in our fertility tables and graphs. However, when ascertaining the fertility effect of the gender revolution and of its components, namely of trends of women's labor force participation and trends of men's involvement in domestic tasks, as well as of the trends of the relationship between these two components (see below), we center the cohort fertility values at age 27 . This means that when associating trends of the gender revolution components (which are period measures) with fertility levels and trends, we graph the completed cohort fertility rates (to age 40) of the respective cohorts as of when they reach age 27 . Specifically, the gender revolution measures around 1960 are associated approximately with the completed cohort fertility rate of the 1933 birth cohort because this cohort reached age 27 in 1960; analogously for measures around 1970 the 1943 total cohort fertility rate is used as the 1943 birth cohort reached age 27 in 1970, and so on. (This will become clearer as we discuss the tables and graphs relating cohort fertility to period measures of gendered behaviors.)

Why age 27 ? It is the age at which most women are in the early career building stages, yet already have enough information about their (likely) male partners to be able to estimate how many children are consistent with their likely second shift of work at home and in the labor force. We realize this is somewhat arbitrary, and women's decisions about work and family might have been formed earlier (particularly among the older cohorts) and continued to evolve as they moved through their childbearing years. Our results, however, were not very sensitive to centering our cohort completed fertility rates at alternate ages, from age 20 , when many women may already have plans for their next decades, to age 35 , when at least some time 
remains, as these produced little change in the story these data seem to tell. In other words, centering cohort fertility values, for instance, on age 29 instead of age 27 would not have changed the results of our investigation.

\subsubsection{Gender revolution measures}

We constructed three gender revolution measures. One focuses on the public sphere (outside the home), the second focuses on the private sphere of the home. The third relates these two measures.

For the public sphere, we examine employment and calculate the ratio of the female labor force participation rate to the male labor force participation rate: the LFPSR (labor force participation sex ratio). Because the female rate has in no country exceeded that of males, our measure ranges between 0 and 1. This measure is not ideal, as men have on average longer commuting times than women and women are far more likely to be employed part time than men (Aguiar/Hurst 2007). ${ }^{1}$ Further, the meaning of "part time" varies widely by country, ranging from work weeks of 12 to 30 hours (Aisenbrey et al. 2009).

Nevertheless, the LFP-SR is widely available over a long period of time. We calculate the gender ratio because our theoretical focus is on the extent to which men and women are sharing a given sphere (in this case, the public sphere). Some are concerned that this inflates women's progress in the public sphere, given that men's labor force participation has been dropping across most of the industrialized world, but this is exactly what we want to observe.

We collected labor force participation rates from several sources. For the most recent period (1990 and later), we accessed the World Bank Database (2016). The Organisation for Economic Co-Operation and Development (OECD 2016) provided information for nine of our eleven countries (all but France and the United Kingdom) from 1970 onward (and their values for 1990 closely matched those from the World Bank). We were able to obtain data for France and the UK for 1970 from Mitchell (1998). Individual International Labour Office (ILO) Yearbooks of Labour Statistics form the basis for our 1960 data, although dating precision was not always possible. The closest we could obtain for our 1960 estimate for Norway was 1950, for the UK, 1951, and for the Netherlands, 1956, the most extreme cases.

While more limited, our data for private sphere activities were more easily obtained. We used Table 1 in Kan et al. (2011), which included information on total

1 The countries studied here vary both in the proportions of women who work part time and in the number of hours part-time workers currently average (Grunow/Evertsson 2016). In 2002, most countries are concentrated at about 20-25 percent of employed women working part time but Norway (33 percent), Germany (35 percent), the United Kingdom (40 percent) and most strikingly, the Netherlands (59 percent), have considerably higher levels (OECD 2016). Unfortunately, we were not able to obtain consistent information on part-time work for our countries over the entire period. 
domestic hours (including childcare) for all men and women aged 20 to 59 years $^{2}$ on our 11 countries for the period 1961 to $2004{ }^{3}$ We had to be less precise with dates, given the wide variability in when time-use surveys were conducted in these countries, and made liberal use of interpolation to fill holes between surveys. Again, we created a sex ratio of these hours (but this time: male to female), the TDH-SR (total domestic hours sex ratio). Because in no country have men's average domestic hours exceeded women's, the TDH-SR, like the LFP-SR, ranges between 0 and 1 .

Finally, we constructed a third gender revolution measure, which we call the "second shift ratio" (SSR). It is the ratio of our labor force participation ratio (the LFP-SR) divided by the domestic hours ratio (the TDH-SR), and normally ranges from 1 to 2 , but exceptionally even exceeds 2 . If these two ratios were equal, the combined ratio would equal one, meaning that women's participation in the public sphere relative to men's is roughly balanced by men's participation in the private sphere relative to women's. Values above one indicate that the gender gap in the public sphere has closed more than the gender gap in the private sphere, leaving women on average with a second shift of domestic work beyond their involvement in paid employment.

\subsection{Methods}

This is a descriptive analysis, which rests on our examination of trends between the 1960 s and the early years of the $21^{\text {st }}$ century in these four indicators for these 11 countries. As more data become available (especially for men's involvement in the private sphere), it might become possible to use more advanced statistical techniques to test what are essentially our hunches about the patterns we see in these trends, as we will spell out in the analysis that follows. At this point, however, we simply describe patterns and make linkages among them for clusters of countries.

\section{$4 \quad$ Results}

We first examine trends in total cohort fertility and then link these trends to overall changes in the three ratio measures for our full set of countries. We group countries

2 Hence, the data include those with and without partners, parents and nonparents. With the exception of childcare, it is not clear how country variations in levels of parenthood and union membership would affect our results. It could introduce a small amount of reverse causality, given that gender equality appears to contribute to continued childbearing at the couple level, and contribute, as well, to union formation and retard union dissolution (Goldscheider et al. 2015)

3 Unfortunately, we were not able to use more recent analyses of private sphere trends (Altintas/ Sullivan 2016, 2017), as the first focused only on a subset of domestic chores, to the exclusion both of tasks normally done by men and of childcare, where men's participation has recently been rising rapidly, at least in the United States (Aguiar/Hurst 2007). The second study, while it did focus on childcare, was restricted to men with at least one child under the age of five. 
into geographic regions. Each regional group generally shows similar patterns in these ratios, although with important exceptions.

\subsection{Completed cohort fertility as of age $\mathbf{4 0}$}

The levels and trends in cohort fertility evident in Table 1 and Figure 1 are shown both as of the year these women reached age 27 and the year of birth. For example, the values for 1960 are those for the birth cohort of 1933, who reached age 27 in 1960 (and reached their near complete fertility at age 40 in 1973). Similarly, the values for 2000 are those for the birth cohort of 1973, who reached age 27 in 2000 (and age 40 in 2013).

In Northern Europe, the youngest 20 to 30 cohorts in Finland and Norway, born during the 1950s, 1960s and early 1970s, reached a fairly stable plateau close to replacement of around 2.0 births per woman (Fig. 1A). Sweden has actually experienced an approximately replacement level of cohort fertility for over 50 cohorts. ${ }^{4}$

The two countries in North America experienced relatively high fertility in the 1930s birth cohorts, with CTFRs above 3.0 followed by sharp declines between the cohorts born in the early 1930s up to those born around 1950 (Table 1 and Fig. 1C). They did not approach the replacement level of the north European countries until the birth cohorts of the early 1950s (like Norway), after which Canada continued a slow decline and the United States, unlike Northern Europe, experienced a slight increase.

Somewhat different patterns characterize both Western/central Europe and Southern Europe (Table 1 and Fig. 1B, 1D). These two regions experienced much lower fertility among more recent cohorts than the two previously described regions (except France). France most closely resembles the countries of Northern Europe, reaching a similarly slightly declining CTFR plateau for the younger 1950s, 1960s and early 1970s birth cohorts at a level around 2.0, after prior declines. Cohort fertility in Germany, the United Kingdom, and the Netherlands declined almost continuously among the youngest birth cohorts born between the late 1940s and early 1970s. This was also the case for the two countries in Southern Europe, except that their cohort fertility declined further and faster, reaching lowest-low CTFRs of 1.4 (Italy) and 1.3 (Spain) in the early 1970s birth cohorts.

An important result of these differing patterns of change is the reversal in country fertility levels that has been so frequently remarked upon. Italy and Spain had the highest fertility in the 1940 s birth cohorts and early in the $21^{\text {st }}$ century have the lowest fertility in the mid-1970s cohorts, as a result of their sharp declines. Finland, Norway and Sweden, which had relatively low fertility among the 1940s cohorts, now have among the highest fertility in the mid-1970s cohorts in this set of countries as a result of their relative stability.

4 For each of these countries, childbearing for women in their late $30 \mathrm{~s}$ in the most recent cohort might have been depressed by the world-wide Great Depression, which hit when they were approximately aged 34 . 
Tab. 1: Cohort total fertility rates at age 40 , selected countries, birth cohorts, absolute values and rates of change, 1960-2000 (centered on age 27)

\begin{tabular}{|c|c|c|c|c|c|c|}
\hline \multirow[t]{3}{*}{ Country and region } & \multicolumn{6}{|c|}{ Cohorts } \\
\hline & Year age $27^{a}$ & 1960 & 1970 & 1980 & 1990 & 2000 \\
\hline & Year of birth & 1933 & 1943 & 1953 & 1963 & 1973 \\
\hline \multicolumn{7}{|l|}{ Northern Europe } \\
\hline Finland & & 2.323 & 1.885 & 1.817 & 1.887 & 1.828 \\
\hline Norway & & $2.450^{1}$ & 2.250 & 2.010 & 2.039 & 1.981 \\
\hline Sweden & & 2.118 & 1.960 & 1.986 & 1.971 & 1.879 \\
\hline \multicolumn{7}{|c|}{ Western/Central Europe } \\
\hline France & & 2.578 & 2.268 & 2.086 & 2.014 & 1.929 \\
\hline Germany & & & 1.815 & 1.658 & 1.562 & 1.525 \\
\hline Netherlands & & $2.477^{1}$ & 2.064 & 1.844 & 1.770 & 1.716 \\
\hline United Kingdom & & $2.361^{2}$ & $2.319^{2}$ & $2.008^{2}$ & 1.876 & 1.809 \\
\hline \multicolumn{7}{|l|}{ North America } \\
\hline Canada & & 3.201 & 2.328 & 1.848 & 1.753 & $1.732^{4}$ \\
\hline United States & & 3.231 & 2.444 & 1.937 & 2.000 & 2.147 \\
\hline \multicolumn{7}{|l|}{ Southern Europe } \\
\hline Italy & & $2.182^{3}$ & 2.115 & 1.833 & 1.550 & 1.365 \\
\hline Spain & & 2.554 & 2.429 & 2.006 & 1.608 & 1.317 \\
\hline \multirow{2}{*}{\multicolumn{2}{|c|}{ Country and region }} & \multicolumn{5}{|c|}{$\begin{array}{l}\text { Average annual rate of change between centered } \\
\text { cohorts on age } 27 \text { (in percent) }\end{array}$} \\
\hline & & $\begin{array}{l}1960- \\
1970\end{array}$ & $\begin{array}{l}1970- \\
1980\end{array}$ & $\begin{array}{l}1980- \\
1990\end{array}$ & $\begin{array}{l}1990- \\
2000\end{array}$ & $\begin{array}{l}1960- \\
2000\end{array}$ \\
\hline \multicolumn{7}{|l|}{ Northern Europe } \\
\hline Finland & & -2.1 & -0.4 & 0.4 & -0.3 & -0.6 \\
\hline Norway & & $-1.1^{5}$ & -1.1 & 0.1 & -0.3 & $-0.6^{8}$ \\
\hline Sweden & & -0.8 & 0.1 & -0.1 & -0.5 & -0.3 \\
\hline \multicolumn{7}{|c|}{ Western/Central Europe } \\
\hline France & & -1.3 & -0.8 & -0.4 & -0.4 & -0.7 \\
\hline Germany & & & -0.9 & -0.6 & -0.2 & -0.6 \\
\hline Netherlands & & $-2.3^{5}$ & -1.1 & -0.4 & -0.3 & $-1.0^{8}$ \\
\hline United Kingdom & & -0.2 & -1.4 & -0.7 & -0.4 & -0.7 \\
\hline \multicolumn{7}{|l|}{ North America } \\
\hline Canada & & -3.2 & -2.3 & -0.5 & $-0.1^{7}$ & $-1.6^{9}$ \\
\hline United States & & -2.8 & -2.3 & 0.3 & 0.7 & -1.0 \\
\hline \multicolumn{7}{|l|}{ Southern Europe } \\
\hline Italy & & $-0.8^{6}$ & -1.4 & -1.7 & -1.3 & $-1.4^{10}$ \\
\hline Spain & & -0.5 & -1.9 & -2.2 & -2.0 & -1.7 \\
\hline
\end{tabular}

Notes: ${ }^{a}$ refers to the year the respective cohort reached age 27: For example, the values for 1960 are those for the birth cohort of 1933, who reached age 27 in 1960; ${ }^{1} 1962 ;{ }^{2}$ England and Wales; ${ }^{3}$ 1966; 4 1998; ${ }^{5}$ 1962-1970; ${ }^{6}$ 1966-1970; 7 1990-1998; 8 ' 1962-2000; 9 1960-1998; 10 1966-2000

Source: HFD 2018; Lappegård 2018 (for Norway 1962 \& 1970) 
Fig. 1: Cohort total fertility rates at age 40, Northern, Western/Central Europe, North America, Southern Europe, birth cohorts 1920-1975
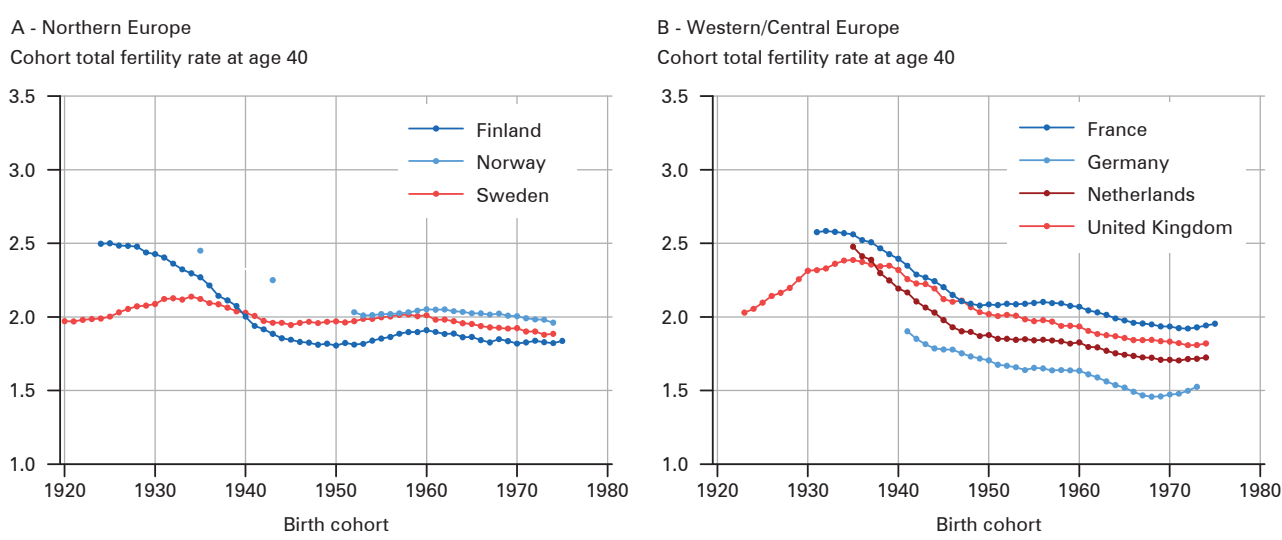

C - North America

Cohort total fertility rate at age 40

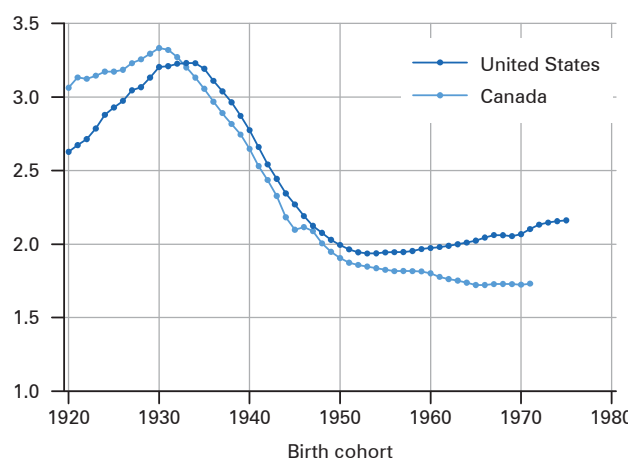

D - Southern Europe

Cohort total fertility rate at age 40

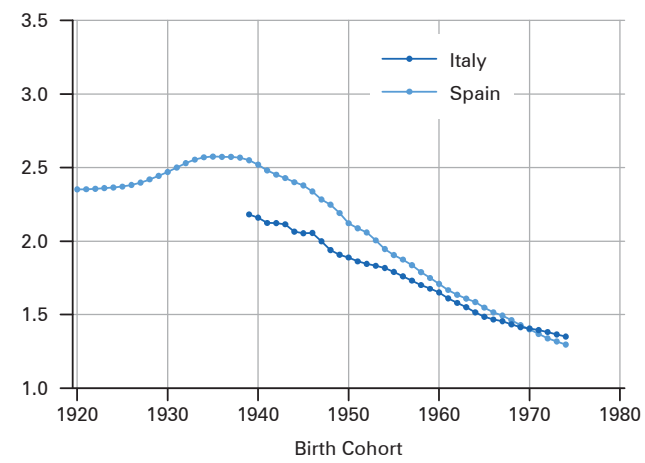

Source: HFD 2018

In sum, among the recent youngest approximately 40 cohorts, born between the 1930s and the early 1970s, fertility declined in all the analyzed countries (Table 1, last column, lower panel; Fig. 1). Further, the overall propensity for contemporary fertility to fall off among western countries is confirmed by the moderate fertility declines among the youngest 15 to 20 birth cohorts, those born in the 1960s and early 1970s, in all countries with the exception of the United States (Table 1, column 1990-2000, lower panel; Fig. 1). Given these various country patterns of cohort total fertility rates, the question we now ask is how these fertility patterns of the late twentieth century relate to changes in our three measures of gender change - labor force participation, domestic hours, and women's second shift.

\subsection{Labor force participation: The LFP-SR}

The massive change in the public sphere gender balance between 1960 and 2010 is evident in Table 2 and Figure 2, which show, by region and country, the sex ratio of 
Tab. 2: Ratio of female to male labor force participation rates, LFP-SR, selected countries, absolute values and rates of change, 1960-2014

\begin{tabular}{|c|c|c|c|c|c|c|c|}
\hline \multirow{2}{*}{$\begin{array}{l}\text { Country and } \\
\text { Region }\end{array}$} & \multicolumn{7}{|c|}{ Ratio of female to male labor force participation rate LFP-SR in year } \\
\hline & 1960 & 1970 & 1980 & 1990 & 2000 & 2010 & 2014 \\
\hline \multicolumn{8}{|l|}{ Northern Europe } \\
\hline Finland & 0.620 & 0.722 & 0.862 & 0.908 & 0.929 & 0.946 & 0.947 \\
\hline Norway & 0.305 & 0.549 & 0.714 & 0.845 & 0.899 & 0.936 & 0.949 \\
\hline Sweden & 0.435 & 0.640 & 0.832 & 0.952 & 0.937 & 0.931 & 0.944 \\
\hline \multicolumn{8}{|c|}{ Western/Central Europe } \\
\hline France & 0.471 & 0.530 & 0.655 & 0.760 & 0.830 & 0.880 & 0.890 \\
\hline Germany & 0.568 & 0.452 & 0.559 & 0.703 & 0.802 & 0.860 & 0.871 \\
\hline Netherlands & 0.206 & 0.229 & 0.367 & 0.660 & 0.783 & 0.867 & 0.882 \\
\hline United Kingdom & 0.411 & 0.579 & 0.660 & 0.770 & 0.820 & 0.850 & 0.860 \\
\hline \multicolumn{8}{|l|}{ North America } \\
\hline Canada & 0.374 & 0.531 & 0.602 & 0.806 & 0.859 & 0.910 & 0.913 \\
\hline United States & 0.475 & 0.521 & 0.659 & 0.795 & 0.845 & 0.863 & 0.855 \\
\hline \multicolumn{8}{|l|}{ Southern Europe } \\
\hline Italy & 0.369 & 0.297 & 0.421 & 0.566 & 0.628 & 0.697 & 0.726 \\
\hline Spain & 0.210 & 0.260 & 0.310 & 0.521 & 0.658 & 0.816 & 0.855 \\
\hline Country and & \multicolumn{7}{|c|}{ Average annual rate of change in period (in percent) } \\
\hline Region & $1960-$ & $1970-$ & $1980-$ & $1990-$ & $2000-$ & $2010-$ & \\
\hline & 1970 & 1980 & 1990 & 2000 & 2010 & 2014 & \\
\hline \multicolumn{8}{|l|}{ Northern Europe } \\
\hline Finland & 1.5 & 1.8 & 0.5 & 0.2 & 0.2 & 0.0 & \\
\hline Norway & 5.9 & 2.6 & 1.7 & 0.6 & 0.4 & 0.3 & \\
\hline Sweden & 3.9 & 2.6 & 1.3 & -0.2 & -0.1 & 0.3 & \\
\hline \multicolumn{8}{|c|}{ Western/Central Europe } \\
\hline France & 1.2 & 2.1 & 1.5 & 0.9 & 0.6 & 0.3 & \\
\hline Germany & -2.3 & 2.1 & 2.3 & 1.3 & 0.7 & 0.3 & \\
\hline Netherlands & 1.1 & 4.7 & 5.9 & 1.7 & 1.0 & 0.4 & \\
\hline United Kingdom & 3.4 & 1.3 & 1.5 & 0.6 & 0.4 & 0.3 & \\
\hline \multicolumn{8}{|l|}{ North America } \\
\hline Canada & 3.5 & 1.3 & 2.9 & 0.6 & 0.6 & 0.1 & \\
\hline United States & 0.9 & 2.3 & 1.9 & 0.6 & 0.2 & -0.2 & \\
\hline \multicolumn{8}{|l|}{ Southern Europe } \\
\hline Italy & -2.2 & 3.5 & 3.0 & 1.0 & 1.0 & 1.0 & \\
\hline Spain & 2.1 & 1.8 & 5.2 & 2.3 & 2.2 & 1.2 & \\
\hline
\end{tabular}

Source: Authors' calculations based on World Bank Databank 2016; OECD 2016; Mitchell 1998; ILO 1960

female to male labor force participation, the LFP-SR. Clearly, at least at the macrolevel, the bivariate relationship between changing cohort fertility and the changing ratio of female to male labor force participation is inverse. Further, in most cases the pattern of change at least loosely follows that for cohort fertility (in reverse), with 
Fig. 2: Ratio of female to male labor force participation rates (LFPR-SR), selected countries, 1960-2010

Ratio: female to male labor force participation rates LFP-SR

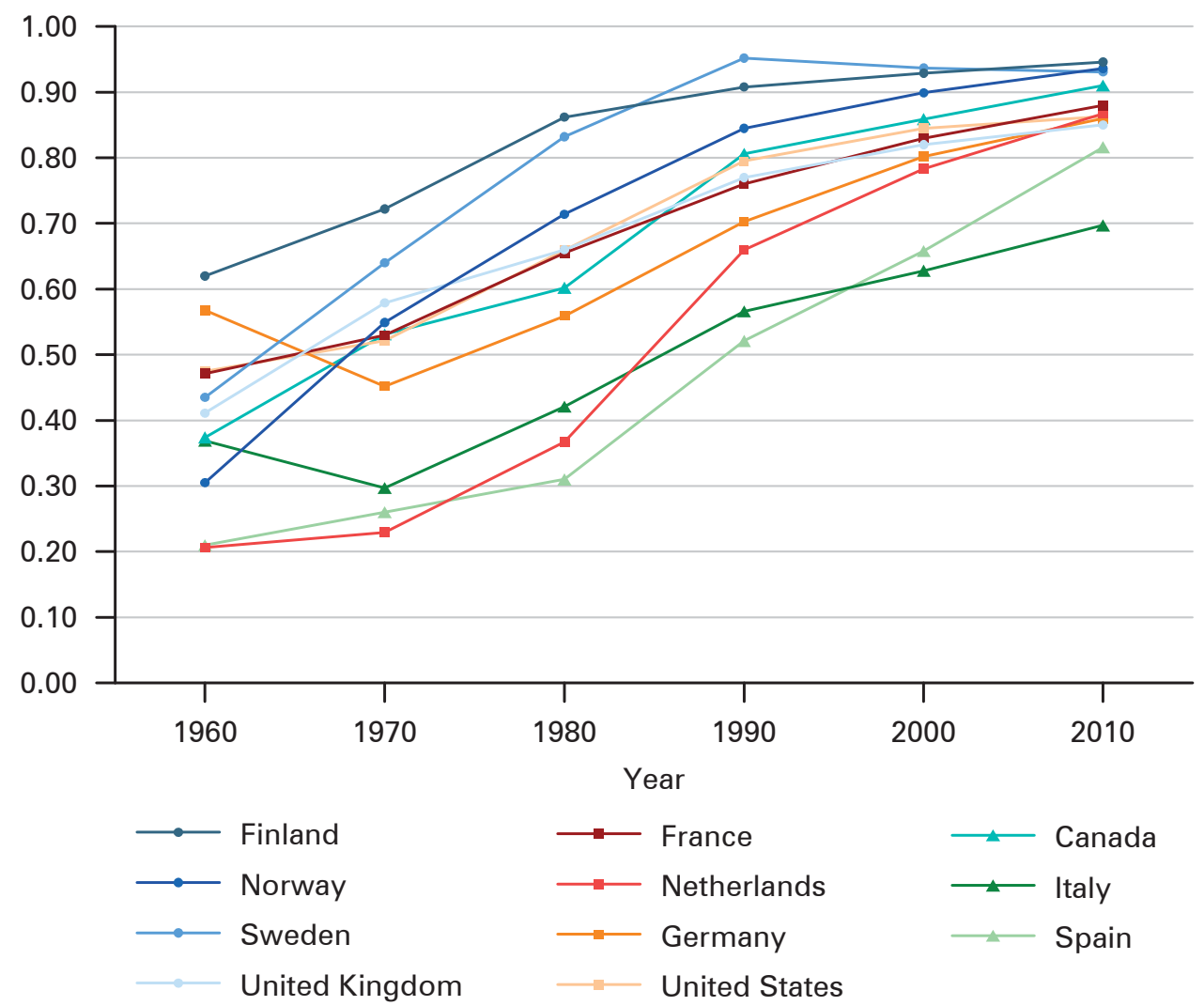

Source: Authors' calculations based on World Bank Databank 2016; OECD 2016; Mitchell 1998; ILO 1960

either early rapid change followed by a near plateau or relatively continuous fairly rapid change (increases in the FLP-SR; decreases in cohort total fertility).

However, in the early years, the levels were very different, and, as with fertility, the trends changed the relative levels substantially, primarily because of differing intensities of change. There was a wide range among these countries in the LFPSR in 1960. Two countries had ratios as low as 0.20 (Spain and the Netherlands); while Finland ${ }^{5}$ was at the high end $(0.62) .{ }^{6}$ Differences were much smaller by the

5 Given that Germany's LFP-SR fell substantially between 1960 and 1970, only recovering to its 1960 level in 1980, we do not take the original measure very seriously.

As previously noted, several countries' measures for 1960 are actually from the 1950 s. More timely measures for Norway and the United Kingdom might have registered considerably higher levels, but this seems unlikely for the Netherlands, given their very low level in 1970. 
end of the period in 2014. The LFP-SR increased rapidly to settle at a level around 0.90 in 1990 in Northern Europe; in Western/central Europe and in North America the process was more gradual, reaching close to 0.90 only in 2010; and in Southern Europe, levels all along were lower than elsewhere, reaching 0.70 to 0.80 early in the $21^{\text {st }}$ century. Hence, in more recent years there has been substantial convergence. This pattern of convergence is even evident within regions. The three Northern European countries show quite different LFP-SRs in 1960, ranging from Finland's high ratio of 0.62 down to Norway's 0.31, with Sweden in between. However, their massive increases after 1960 led to LFP-SRs above 0.80 in the 1980s, and essentially to total convergence at about 0.90 around 1990, even reaching 0.95 in 2014. (Norway lagged slightly for most of this period.)

As these trends suggest, however, there was considerable variation in temporal patterns. In the early part of the period (1960-1970), some countries were rapidly accelerating (Norway, Sweden), with annual rates of change of 5.9 percent and 3.9 percent (Table 2). Some were barely increasing (the Netherlands, France, and the U.S.), with annual rates of change of around 1 percent; and some were even decreasing (Germany, ${ }^{7}$ Italy), with annual rates of change of -2 percent.

Yet all these countries experienced declines in cohort fertility during that period, and the rates of fertility decline only very loosely matched the rates of increase in the LFP-SR. For example, between 1960 and 1970, Finland experienced the slowest increase in the LFP-SR (admittedly from a high base) but the fastest decline in cohort fertility. Nevertheless, the overall patterns of fertility change and change in the sex ratios for labor force participation suggest that the first half of the gender revolution is far from complete in many of these countries, and its negative effects on fertility are likely far from complete, as well.

\subsection{Domestic work hours: The TDH-SR}

The two-stage approach to the gender revolution posits that change came first in the public sphere, with the increase in female labor force participation, and that this was followed by change in the private sphere, as men, after some delay, increased their engagement in the tasks of the home (Anderson/Kohler 2015; Esping-Andersen/Billari 2015; Goldscheider et al. 2015). Our results suggest, however, that this is an oversimplification, at least to some extent. From the earliest days of the gender revolution, as early as the 1960 s, the general pattern is that men have been increas-

7 The data for Germany combine the former East Germany with the former West Germany. This is somewhat problematic in this case, as the gender systems in these two (then) countries evolved in very different ways during the $40+$ years that they were separated. The former East Germany emphasized gender equality (particularly in the public sphere); the proportions of women who were reported to be housewives were very different (Klein/Nauck 2005). In the former East Germany, only 9 percent of women and 10 percent of men prefer that when a couple become parents "one should stay at home" during the preschool years, while in the former West Germany, 56 percent of women and 63 percent of men gave that response (Dannenbeck 1992). Unlike in the US, in West Germany most couples are not concerned about domestic equality (Bellani et al. 2017). 
Tab. 3: $\quad$ Ratio of male to female total domestic hours worked, TDH-SR, selected countries, absolute values and rates of change, 1960-1969 to 2000-2004

\begin{tabular}{|c|c|c|c|c|c|c|c|}
\hline \multirow{4}{*}{$\begin{array}{l}\text { Country and } \\
\text { Region }\end{array}$} & \multicolumn{7}{|c|}{ Ratio of male to female total domestic work TDH-SR in period } \\
\hline & $1960-69$ & $1970-75$ & $1976-84$ & $1985-89$ & $1990-94$ & $1995-99$ & $2000-04$ \\
\hline & \multicolumn{7}{|c|}{ “Central years" } \\
\hline & 1965 & 1972.5 & 1980 & 1987.5 & 1992 & 1997 & 2002 \\
\hline \multicolumn{8}{|l|}{ Northern Europe } \\
\hline Finland & & & 0.486 & 0.578 & 0.583 & 0.588 & \\
\hline Norway & & 0.341 & 0.452 & 0.504 & 0.556 & 0.591 & 0.627 \\
\hline Sweden & & & & & 0.592 & 0.642 & 0.693 \\
\hline \multicolumn{8}{|c|}{ Western/Central Europe } \\
\hline France & 0.268 & 0.310 & 0.362 & 0.415 & 0.467 & 0.520 & \\
\hline Germany & 0.330 & 0.368 & 0.405 & 0.442 & 0.480 & 0.505 & 0.531 \\
\hline Netherlands & & 0.331 & 0.350 & 0.390 & 0.406 & 0.472 & 0.478 \\
\hline United Kingdom & 0.244 & 0.300 & 0.358 & 0.416 & 0.458 & 0.500 & 0.529 \\
\hline \multicolumn{8}{|l|}{ North America } \\
\hline Canada & & 0.372 & 0.502 & 0.464 & 0.522 & 0.574 & \\
\hline United States & 0.291 & 0.413 & 0.472 & 0.531 & 0.588 & 0.671 & 0.636 \\
\hline \multicolumn{8}{|l|}{ Southern Europe } \\
\hline Italy & & & & 0.184 & 0.217 & 0.251 & 0.284 \\
\hline Spain & & & & & & & 0.331 \\
\hline Country and & & Average an & nual rate & f change $i$ & n period ( & n percent) & \\
\hline \multirow[t]{2}{*}{ Region } & 1965- & 1972.5- & 1980- & 1987.5- & 1992- & $1997-$ & \\
\hline & 1972.5 & 1980 & 1987.5 & 1992 & 1997 & 2002 & \\
\hline \multicolumn{8}{|l|}{ Northern Europe } \\
\hline Finland & & & 2.3 & 0.2 & 0.2 & & \\
\hline Norway & & 3.8 & 1.4 & 2.2 & 1.2 & 1.2 & \\
\hline Sweden & & & & & 1.6 & 1.5 & \\
\hline \multicolumn{8}{|c|}{ Western/Central Europe } \\
\hline France & 1.9 & 2.1 & 1.8 & 2.6 & 2.1 & & \\
\hline Germany & 1.4 & 1.3 & 1.2 & 1.8 & 1.0 & 1.0 & \\
\hline Netherlands & & 0.7 & 1.4 & 0.9 & 3.0 & 0.3 & \\
\hline United Kingdom & 2.8 & 2.3 & 2.0 & 2.1 & 1.8 & 1.1 & \\
\hline \multicolumn{8}{|l|}{ North America } \\
\hline Canada & & 4.0 & -1.0 & 2.6 & 1.9 & & \\
\hline United States & 4.7 & 1.8 & 1.6 & 2.3 & 2.6 & -1.1 & \\
\hline \multicolumn{8}{|l|}{ Southern Europe } \\
\hline Italy & & & & 3.7 & 2.9 & 2.5 & \\
\hline Spain & & & & & & & \\
\hline
\end{tabular}

Note: Values in italics are interpolated

Source: Authors' calculations based on Kan et al. 2011

ing their share of hours in the private sphere relative to women (Table 3 and Fig. 3). Although much of the increase in the sex ratio of total domestic time (TDH-SR) in the early years reflects women's massive decline in housework hours, men did ex- 
Fig. 3: Ratio of male to female total domestic hours worked (TDH-SR), selected countries, absolute values, 1960-1969 to 2000-2004

Ratio: male to female total domestic work TDH-SR

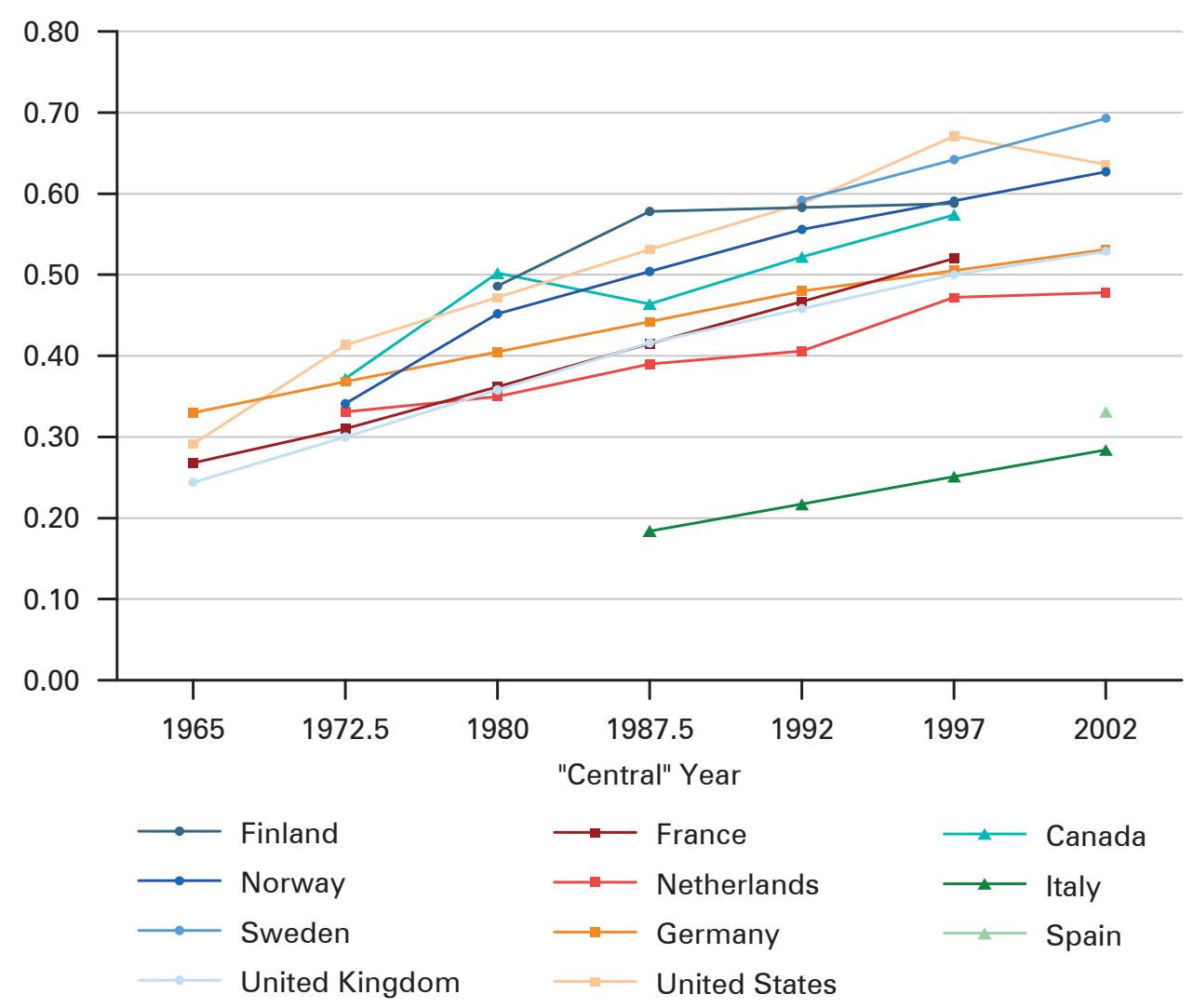

Source: Authors' calculations based on Kan et al. 2011

perience a non-trivial absolute increase in non-market work in most of these countries. Men in the United States increased their weekly non-market work by about three hours (Aguiar/Hurst 2009; Kan et al. 2011); smaller but substantial increases occurred among men in Canada, the Netherlands, Norway, Finland, Germany and Italy; only in France and the United Kingdom did men not experience an increase between the first two time-use surveys (and Swedish men show a decline; just a smaller one than among Swedish women) (Kan et al. 2011).

Figure 3 indicates that the differences between the patterns of change in these two halves of the gender revolution are more about level and pace of change than about timing relative to each other. Comparing Figures 2 and 3, it is clear that the level is always higher for the LFP-SR than for the TDH-SR. Similarly, a comparison of the rates of change shown in Tables 2 and 3 shows that the pace of change is, with few exceptions, greater for the LFP-SR than for the TDH-SR, particularly in the 
early years. The timing is similar, however, both beginning to increase as early as the 1960s.

Although the general level of the TDH-SR remained lower than the LFP-SR throughout the period, the regional variation in TDH-SR trends fairly closely resembles the regional variation we observed for the LFP-SR, with high levels for the North European countries and low levels for the South European countries, with the Western/central countries in between. The major differences in regional patterns between these two sets of ratios (LFP and TDH) are for the two North American countries, and most dramatically, for the United States. While these two countries ranked among those in the middle for the LFP-SR, they rank among the North European leaders for the TDH-SR, again, particularly the United States, despite the dip or "stall" (England 2010) in the recent period.

Hence, the overall patterns of change in gender behavior in the private sphere of the family appear to do little to account for change in cohort fertility. Taken together, one could even argue that increasing men's share (the TDH-SR) reduces fertility, instead of increasing it, given that as with the LFP-SR, the relationships are inverse increases in men's share, decreases in cohort fertility. But what might be operating is not the absolute trends in the LFP-SR and the TDH-SR, but their relationships with each other - women's second shift - to which we now turn.

\subsection{Relating the two ratios: the second shift}

For our final measure of gender change, we calculated a "ratio of ratios" for these countries (Table 4 and Fig. 4), dividing the public sphere ratio by the private sphere ratio for each country and time. This is our indicator of the size of women's "second shift," albeit at the macro level, as it relates how close women have come to equality in the public sphere (the numerator) to how close they have come to equality in the private sphere (the denominator). Hence, in this case, the "second shift ratio" (SSR) throughout is almost always above one ${ }^{8}$ indicating more equal gender sharing in the public sphere than in the private sphere. The higher the value, the greater the second shift.

The overall impression of the SSR data shown in Table 4 is that women's burden is considerably greater than men's. There was little pattern and little change prior to 1990 , as shown by the largely random pattern of percent change in the lower part of Table 4. Thereafter, however, the major trend is (slightly) down, indicating a reduction in women's second shift. It is worth noting that the SSR in the year 2000 has converged around the value of 1.5 (except for the Southern European countries). In an evaluation of the overall picture of combined activities in the public and the private spheres, this might be interpreted as women expending about 50 percent more effort than men towards their families' well-being.

8 The Netherlands' strange early value (0.691) reflects women's unusually low ratio of labor force participation rather than anything unusual in Dutch men's domestic participation. 
Tab. 4: Second shift ratio, SSR, selected countries, absolute values and rates of change, 1960 to 2000

\begin{tabular}{|c|c|c|c|c|c|}
\hline \multirow[t]{2}{*}{ Country and Region } & \multicolumn{5}{|c|}{ Second shift ratio (LFP-SR/TDH-SR) } \\
\hline & 1960 & 1970 & 1980 & 1990 & 2000 \\
\hline \multicolumn{6}{|l|}{ Northern Europe } \\
\hline Finland & & & 1.772 & 1.565 & 1.579 \\
\hline Norway & & 1.613 & 1.578 & 1.595 & 1.476 \\
\hline Sweden & & & & & 1.404 \\
\hline \multicolumn{6}{|c|}{ Western/Central Europe } \\
\hline France & 1.757 & 1.712 & 1.807 & 1.723 & \\
\hline Germany & 1.720 & 1.230 & 1.379 & 1.524 & 1.548 \\
\hline Netherlands & & 0.691 & 1.048 & 1.659 & 1.647 \\
\hline United Kingdom & 1.687 & 1.927 & 1.843 & 1.763 & 1.594 \\
\hline \multicolumn{6}{|l|}{ North America } \\
\hline Canada & & 1.426 & 1.200 & 1.636 & \\
\hline United States & 1.632 & 1.264 & 1.396 & 1.421 & 1.293 \\
\hline \multicolumn{6}{|l|}{ Southern Europe } \\
\hline Italy & & & & 2.820 & 2.346 \\
\hline Spain & & & & & 1.994 \\
\hline \multirow[t]{2}{*}{ Country and Region } & \multicolumn{5}{|c|}{ Average annual rate of change in period (in percent) } \\
\hline & $1960-1970$ & $1970-1980$ & $1980-1990$ & $1990-2000$ & \\
\hline \multicolumn{6}{|l|}{ Northern Europe } \\
\hline Finland & & & -1.2 & 0.1 & \\
\hline Norway & & -0.2 & 0.1 & -0.8 & \\
\hline \multicolumn{6}{|l|}{ Sweden } \\
\hline \multicolumn{6}{|c|}{ Western/Central Europe } \\
\hline France & -0.3 & 0.5 & -0.5 & & \\
\hline Germany & -3.4 & 1.1 & 1.0 & 0.2 & \\
\hline Netherlands & & 4.2 & 4.6 & -0.1 & \\
\hline United Kingdom & 1.3 & -0.4 & -0.4 & -1.0 & \\
\hline \multicolumn{6}{|l|}{ North America } \\
\hline Canada & & -1.7 & 3.1 & & \\
\hline United States & -2.6 & 1.0 & 0.2 & -0.9 & \\
\hline \multicolumn{6}{|l|}{ Southern Europe } \\
\hline Italy & & & & -1.8 & \\
\hline Spain & & & & & \\
\hline
\end{tabular}

Source: Authors' calculations based on Tables 2 and 3 
Fig. 4: Second shift ratio (SSR), selected countries, 1960-2000

Second shift ratio - SSR

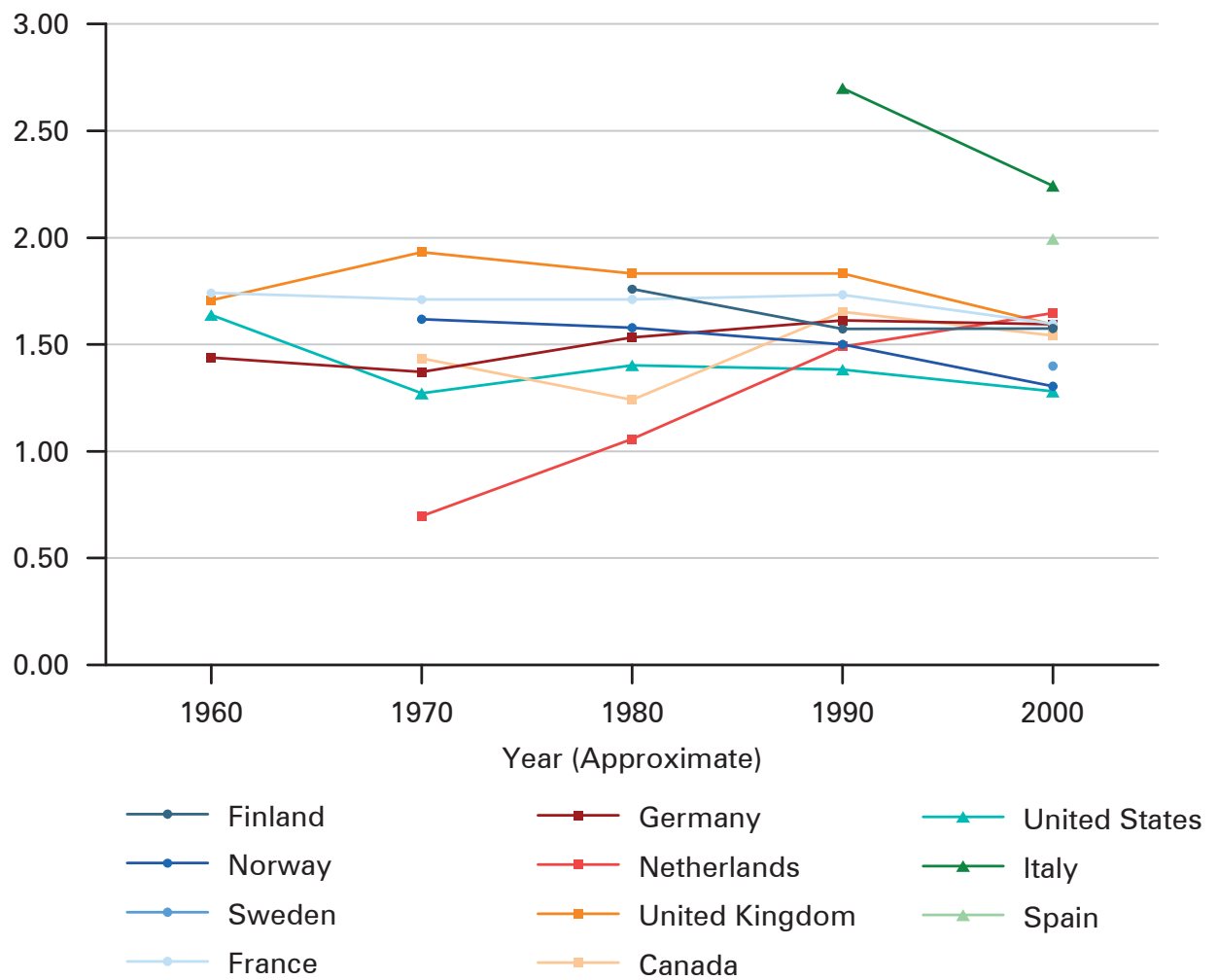

Source: Authors' calculations based on Tables 2 and 3

Three countries show fairly consistent declines throughout the period, indicating overall progress in closing the gap that underlies women's "second shift." Interestingly, they occurred in three different regions. One is in Southern Europe (Italy), which, while it has begun to close its very large SSR, clearly has a long way to go, with ratios above 2. Another country with an overall decline in the SSR is one of the Northern European countries (Norway), which declined from 1.61 in 1970 to 1.48 in 2000. (Finland's SSR tends to be larger than Norway's; however it evinced a large decline (annual decline $=1.2$ percent) between 1980 and 1990.)

None of the countries in Western/central Europe shows an overall consistent decline in the second shift, although two show a dip in the most recent period, after decades of stasis (the United Kingdom and France). In this region and overall, Germany and especially the Netherlands are outliers. Germany shows little trend, and what trend appears seems to be a slight increase in German women's second shift (the 1970 ratio does not seem plausible). The Netherlands actually appears to have experienced a substantial increase in the SSR, particularly between 1980 and 1990. 
And then there is the United States, the third country to show an overall decline. It has also declined the most among these 11 countries, and attained the lowest level in 2000, even below Sweden: the SSR fell from 1.63 in 1960 to 1.29 in 2000, lower than any of the Northern European countries. It is difficult to know what to make of these quite noisy data on the second shift, but if the patterns are real, this could be reflected in their trends in cohort fertility.

As we just saw, the SSR in most countries was declining at the end of the $20^{\text {th }}$ century, yet at the same time cohort fertility was also declining. This appears to be contrary to what might be expected, namely that a declining second shift ratio would generate an increase in cohort fertility, because women's involvement (or burden) is declining. This is also what the papers theorizing about the consequences of the gender revolution assumed would occur (Anderson/Kohler 2015; EspingAndersen/Billari 2015; Goldscheider et al. 2015). Clearly, this has not happened in these countries, an outcome that might result from the continuing downward pressure on childbearing of increasing female labor force participation in so many countries, i.e., the first half of the gender revolution, might reflect a delayed effect, or might reflect the impact of other factors.

Four countries, however, do show the expected pattern, although in the case of three, it is somewhat retrograde. As we noted above, both the Netherlands and Germany not only experienced a decline in fertility, they did so in the context of an actual increase in their second shift ratios over much of the period; this is also the case for Canada (Fig. 4). Only the United States pairs the gender revolution measures in the expected direction. Their second shift not only shrank and became the lowest of all (Fig. 4), but their cohort fertility rate increased between 1980 and 2000 (CTFR40 centered on age 27 - Table 1).

Perhaps more telling than these trends (and the fact that these regions show distinct patterns of cohort fertility rates), the deviations within regions in the levels of fertility seem to fit some of the deviations we have observed in the second shift ratio, both in terms of trends and of timing. This is particularly clear in the Northern European region. Each of the three countries has maintained close to replacement cohort fertility in the recent period, perhaps, as McDonald (2000) has suggested, because of the strong support for raising children provided by the state. However, generally paralleling the findings for the trends and levels of the second shift, Norway has the highest cohort fertility and Finland the lowest.

The countries of Western/central Europe have experienced below replacement fertility in the recent period. The Netherlands and particularly Germany are at the lower end and France at the upper end, with nearly replacement fertility. As with the Northern European countries, the order within region again reflects the signal coming from the SSR trends. Moreover, the relatively high fertility in France is associated with its long history of active family policies, particularly early childcare (OECD 2018; Toulemon et al. 2008).

The second shift ratios also seem consistent with the very low cohort fertility among the Southern European countries. Their increases in the LFP-SR have taken place in the teeth of very little change in the TDH-SR; women have been carrying 
the family largely on their own, as is apparently also the case in Germany and the Netherlands.

And of course, it almost seems plausible that its relatively low second shift values might account for the unusually high fertility in the United States (Frejka 2004). Its low SSR reflects in part its slow increase in the LFP-SR, as the lack of supportive government programs has limited many mothers' ability to stay in the labor market (Daly/Rake 2003). Given that so many in fact do work, however, the same lack of supportive programs means that women's burden is not reduced by the presence of high quality, affordable childcare or paid, job protected parental leave. Hence, the main way that families can obtain the double earnings of a working couple is for men to lend a hand, more than is the case in Europe. The costs are high in terms of family stress, as couples often seek jobs with differing shifts and as a result have to hand off children in complex ways (Presser 2000). Nevertheless, this may partially contribute to the distinctiveness of the United States on these two dimensions unusually high fertility and unusually low levels of the second shift.

We take the analysis a step further by highlighting the component relationships in four countries (Fig. 5). The gender revolution components normally appear in the lower part of each figure, with the ratio of household sharing (the TDH-SR) lower than the ratio of labor force participation (the LFP-SR), both below one. In our selected countries, the second shift ratio (SSR) normally occupies the band between 1 and 1.5 or so, and cohort fertility normally floats at the upper part of each figure. At least, this is the vertical order for Norway (Fig. 5A), a clear gender revolution leader. As there is little variation in Norwegian cohort fertility to be observed among the 1970-2000 birth cohorts, it is difficult to make conclusions, except that maintaining replacement cohort fertility may require progress on the second shift, i.e., progress on the second half of the gender revolution, perhaps aided by public policy.

The patterns for Germany (Fig. 5B) reinforce this possibility, given that its SSR actually rose during most of this period, with cohort fertility falling so far that the two upper lines (for cohort fertility and SSR) actually cross over in the most recent period. The Italian sub-graph (Fig. 5D) further reinforces this interpretation, showing the extreme levels of their second shift actually above their rapidly declining cohort fertility. While unlike Germany, Italy's second shift shows some signs of decline, it is at such a high level that their second shift clearly has a long way to go to have anything other than a depressing effect on fertility.

Finally, the sub-graph for the United States (Fig. 5C) not only supports this interpretation, but even suggests that it experienced fluctuations in fertility that appear to map not only the levels of their second shift, but even its timing. In the first part of the gender revolution, between 1970 and 1980, the United States' second shift was actually rising, due to the rapid increase in the LFP-SR (as in Germany) and the fact that the ratio of men's to women's domestic hours was rising at a slower rate. Significantly, the fertility of the cohorts born in the late 1940s and 1950s was falling sharply, but after 1980, a second "stage" seems to have appeared for the cohorts born in the late 1950s and 1960s, in which fertility is rising as the second shift falls. 
Fig. 5: Gender revolution components and cohort total fertility rates (centered on age 27), selected countries, 1970 to 2000
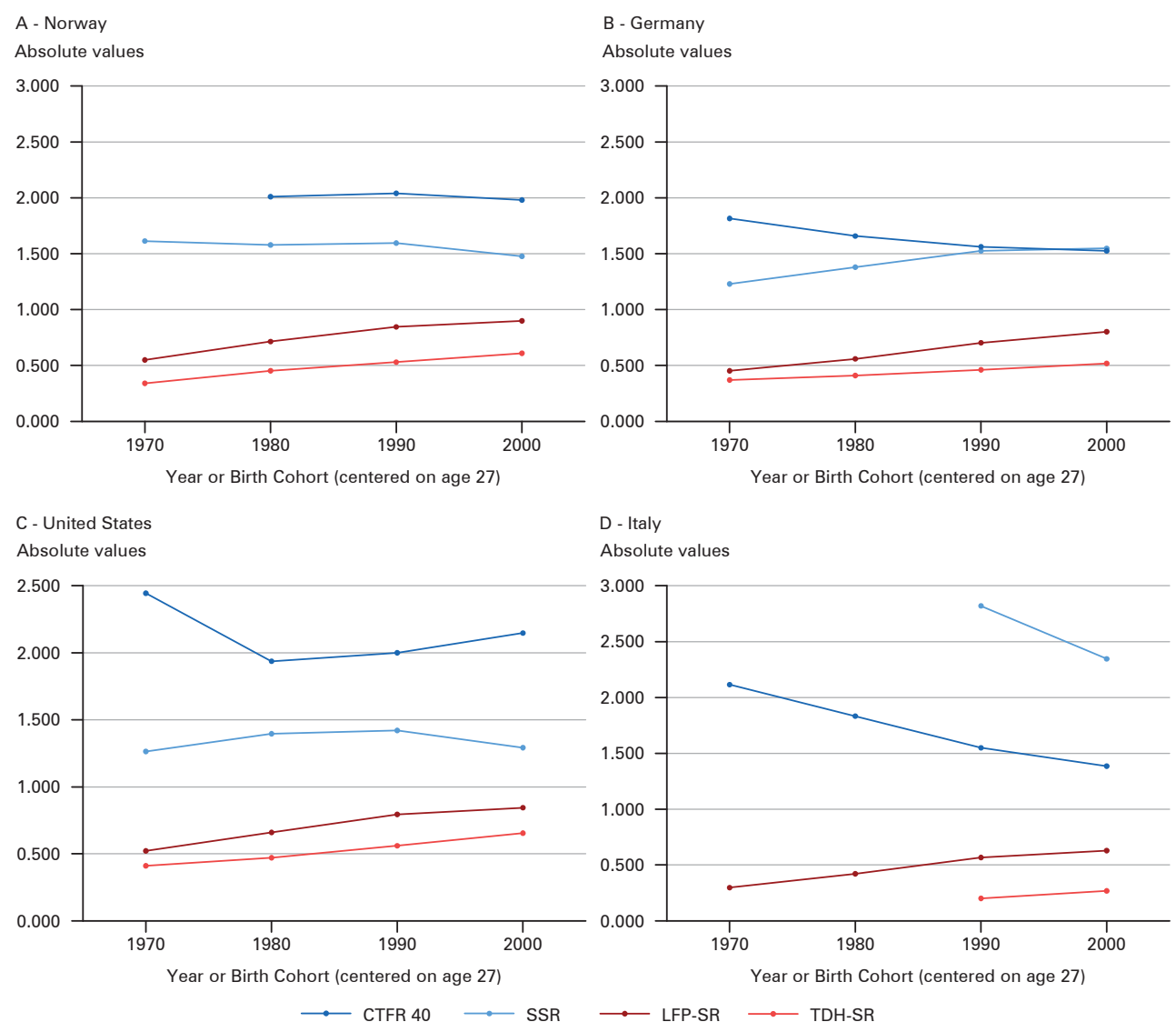

Source: Authors' calculations based on World Bank Databank 2016; OECD 2016; Mitchell 1998; ILO 1960; Kan et al. 2011; and HFD 2018

\section{Summary, Conclusions and Discussion}

The on-going transformation of the male breadwinner family model has been among the most remarkable societal changes of the past 50 to 60 years. This is occurring in two parts: The first part, the growth of female labor force participation, is accompanied by a second part, the growth in men's involvement in the tasks of the home. These overlapping parts are, in essence, the gender revolution. Arguably, the gender revolution is an integral, if late component of societal modernization, emerging out of the demographic transition and the industrial revolution, and their component trends, the technological revolution, the educational revolution, the health transition, and the epidemiological transition. If at first, it disrupted the family, as women experienced the first part by joining the paid labor force more rapidly than 
men took up the tasks of the home, we expect that when men finally increase their involvement in housework and childcare, it will strengthen the family.

In this paper, we examined the relationship between gender equality and fertility, in order to see whether greater gender equality is linked with increased fertility. We studied the cohort total fertility rate (at age 40 ) and related it to three measures of gender equality over the period between 1970 and 2000, with some examination of patterns back to 1960 and up to 2014. Our focus was on the 11 countries in four regions that had the information we needed. In Northern Europe, we examined Finland, Norway and Sweden; in Western/central Europe we examined France, Germany, the Netherlands, and the United Kingdom; in North America we examined Canada and the United States; and in Southern Europe, we examined Italy and Spain.

Based on this information, our objective was to advance knowledge on the unfolding of the gender revolution and its possible impact on fertility. We examined how cohort fertility patterns related to progress in the gender revolution. First, we highlighted progress in the public sphere of employment (a ratio of female to male labor force participation), then we examined trends in the private sphere of the home (a ratio of male to female total hours of domestic work). Finally, we analyzed the progress of the relationship between these two, what we call women's second shift.

The overarching conclusion is that the gender revolution had not generated a turnaround, i.e. an increase in cohort total fertility rates, by the end of the $20^{\text {th }}$ century, possibly because the fertility depressing effects of the first part of the gender revolution are still operative. Nonetheless, in broad terms the evidence suggests that wherever the gender revolution has made significant progress, in particular by reducing women's second shift, cohort fertility declined the least; in Northern Europe cohort fertility has essentially stabilized at replacement. ${ }^{9}$ On the other hand, in countries with the least progress on the gender revolution, and particularly where women's second shift is greater and not shrinking, cohort fertility has experienced the steepest declines, namely in Southern Europe, where it was about 50 percent below replacement. The countries of Western/central Europe and Canada were between these extremes. The United States constitutes an exception, as progress on the gender revolution was associated with an increase in cohort fertility to moderately above replacement.

It is clear that the impressive and widespread growth of the ratio of female to male labor force participation (LFP-SR) is inversely related to cohort total fertility throughout the period, although the rates of fertility decline did not match the rates of increase in the LFP-SR very closely. It is also clear that this first part of the gender revolution is far from complete, suggesting that it will continue to depress fertility in many of those countries, particularly those in Southern Europe, unless, perhaps, those women who are employed have partners who share substantially in house-

9 Note that CTFR values at age 40 at the end of the $20^{\text {th }}$ century have to be increased by $2-3$ percent to provide CTFR values at the end of the reproductive period, which is likely to offset the small declines observed. 
hold work (Pinnelli/Fiori 2006) and childcare and/or effective family friendly policies are introduced that reduce the family/work dilemma.

However, it is also clear that progress on the second part of the gender revolution is inversely related to cohort fertility: many of the patterns are similar, both within and between regions, to those for the first part of the gender revolution. Our analysis shows that progress on the second part of the gender revolution got under way at about the same time as the first part, during the 1960s, contrary to what has been implied in the literature to date. Nevertheless, its progress was clearly much slower than that of the first part of the gender revolution, so that some countries experienced an increase in the second shift, and only recently, during the 1990s, did women's second shift diminish slightly in a majority of countries.

Only a few countries showed signs of an overall second shift decline - Norway, the United States and possibly Italy. Further, even though the second shift declined in a number of countries during the second half of the $20^{\text {th }}$ century, only exceptionally was this trend coupled with an increase in fertility, namely in the United States. There were a few countries - the Netherlands, Germany, and Canada - in which an increase in women's second shift was associated with the decline of fertility, which is what one would expect.

The detailed analysis of trends in the components of the gender revolution confirms the principal conclusion reached in our earlier papers (Frejka et al. 2016a/b), namely that progress on the gender revolution has not yet led to an increase in cohort fertility. In those articles we executed a simpler analysis of the relationship between fertility and progress on the gender revolution, focusing only on the ratio of men's to women's domestic hours, not including the analysis of trends in the ratio of women's to men's labor force participation or the second shift ratio. This analysis allowed us to assess the relatively close connection between trends in the extent of women's "second shift" and cohort fertility. This also takes us beyond the numerous studies that have examined the relationship between fertility and female labor force participation, which ignore the private sphere totally (e.g., Matysiak/Vignoli 2008; Greulich et al. 2016).

Nevertheless, the analysis is only suggestive, given its reliance on simple description and the relatively small numbers of cases we could examine. A further weakness is our inability to examine other factors, such as family-friendly policies and varying levels of part-time employment. France and the three countries in Northern Europe have policies that greatly ease women's work-family conflict, particularly high quality, subsidized childcare. Similarly, places and times where most employed women work part time (as in the Netherlands) or only work a few hours per week (as in the United Kingdom) may experience less downward pressure on cohort fertility than in other places and times where few employed women work part time, whatever the level. Hence, a larger sample with more information might have allowed a multilevel analysis (e.g., Greulich et al. 2016).

Such an analysis might reveal that the unusual pattern displayed by the United States is less a result of greater gender equality at the couple level, resulting from the need for greater male involvement due to the lack of supportive family policies in that country and the dearth of part-time jobs, but more the result of its limited 
availability of contraceptive and abortion services, leading to much unwanted fertility (Frejka 2004; Morgan 2015). By focusing on regions, even in this descriptive analysis we are able to control levels of gender essentialism to some extent (e.g., Baizan et al. 2016; Brinton/Lee 2016), but problems of rigidity in the labor market are less regional (Matysiak/Vignoli 2008). If, however, it encourages more research that focuses on the gender revolution, and in particular, on its two parts (Goldscheider et al. 2015) and the relationships between them, it will have made a significant contribution.

\section{References}

Aguiar, Mark; Hurst, Erik 2007: Measuring trends in leisure: The allocation of time over five decades. In: Quarterly Journal of Economics 122,3: 969-1006 [doi: 10.1162/ qjec.122.3.969].

Aguiar, Mark; Hurst, Erik 2009: A summary of trends in American time allocation: 19652005. In: Social Indicators Research 93,1: 57-64 [doi: 10.1007/s11205-008-9362-0].

Ahn, Namkee; Mira, Pedro 2002: A note on the changing relationship between fertility and female employment rates in developed countries. In: Journal of Population Economics 15,4: 667-682 [doi: 10.1007/s001480100078].

Aisenbrey, Silke; Evertsson, Marie; Grunow, Daniela 2009: Is there a career penalty for mothers' time out? A comparison of Germany, Sweden and the United States. In: Social Forces 88,2: 573-606 [doi: 10.1353/sof.0.0252].

Altintas, Evrim; Sullivan, Orie/ 2016: 50 years of change updated: Cross-national gender convergence in housework. In: Demographic Research 35,16: 455-470 [doi: 10.4054/ DemRes.2016.35.16].

Altintas, Evrim; Sullivan, Orie/ 2017: Trends in fathers' contribution to housework and childcare under different welfare policy regimes. In: Social Politics 24,1: 81-108 [doi: 10.1093/sp/jxw007].

Anderson, Thomas; Kohler, Hans-Peter 2015: Low fertility, socioeconomomic development, and gender equity. In: Population and Development Review 41,3: 381-407 [doi: 10.1111/j.1728-4457.2015.00065.x].

Arpino, Bruno; Esping-Andersen, Gøsta; Pessin, Léa 2015: How do changes in gender role attitudes towards female employment influence fertility? A macro-level analysis. In: European Sociological Review 31,3: 370-382 [doi: 10.1093/esr/jcv002].

Baizan, Pau; Arpino, Bruno; Delclòs, Carlos 2016: The effect of gender policies on fertility: The moderating role of education and normative context. In: European Journal of Population 32,1: 1-30 [doi: 10.1007/s10680-015-9356-y].

Beaujot, Roderic; Du, Ching Jiangqin; Ravenera, Zenaida 2013: Family policies in Quebec and the rest of Canada: Implications for fertility, child-care, women's paid work, and child development indicators. In: Canadian Public Policy 39,2: 221-239 [doi: 10.3138/CPP.39.2.221].

Bellani, Daniela; Esping-Andersen, Gøsta; Pessin, Lea 2017: When equity matters for marital stability: Comparing German and U.S. couples. In: Journal of Social and Personal Relationships 35,9: 1273-1298 [doi: 10.1177/0265407517709537]. 
Bernhardt, Eva; Goldscheider, Frances 2006: Gender equality, parenthood and first births in Sweden. In: Billari, Francesco C.; Liefbroer, Aart C.; Philipov, Dimiter (Eds.): Special Issue on "Postponement of childbearing in Europe." In: Vienna Yearbook of Population Research 4: 19-39.

Bongaarts, John; Feeney, Griffith 1998: On the quantum and tempo of fertility. In: Population and Development Review 24,2: 271-291 [doi: 10.2307/2807974].

Brewster, Karen L.; Rindfuss, Ronald R. 2000: Fertility and women's employment in industrialized nations. In: Annual Review of Sociology 26,1: 271-296 [doi: 10.1146/annurev.soc.26.1.271].

Brinton, Mary C.; Lee, Dong-Ju 2016: Gender-Role ideology, labor market institutions, and post-industrial fertility. In: Population and Development Review 42,3: 405-433 [doi: 10.1111/padr.161].

Brodmann, Stefanie; Esping-Andersen, Gøsta; Güell, Maia 2007: When fertility is bargained: Second births in Denmark and Spain In: European Sociological Review 23,5: 599-613 [doi: 10.1093/esr/jcm025].

Cherlin, Andrew J. 2014: Labor's Love lost: The rise and fall of the working-class family in America. New York: The Russell Sage Foundation.

Cherlin, Andrew 2016: A happy ending to a half-century of family change? In: Population and Development Review 42,1: 121-129 [doi: 10.1111/j.1728-4457.2016.00111.x].

Comolli, Chiara Ludovica 2017: The fertility response to the Great Recession in Europe and the United States: Structural economic conditions and perceived economic uncertainty. In: Demographic Research 36,51: 1549-1600 [doi: 10.4054/DemRes.2017.36.51].

Cooke, Lynn Prince 2009: Gender equity and fertility in Italy and Spain. In: Journal of Social Policy 38,1: 123-140 [doi: 10.1017/S0047279408002584].

Cowan, Ruth 1983: More work for mother. The ironies of household technology from the open hearth to the microwave. New York: Basic Books.

Daly, Mary; Rake, Katherine 2003: Gender and the Welfare State. New York: John Wiley.

Dannenbeck, Clemens 1992: Einstellungen zur Vereinbarkeit von Familie und Beruf. In: Bertram, Hans (Ed.): Die Familie in den neuen Bundesländern. Stabilität und Wandel in der gesellschaftlichen Umbruchsituation. Opladen: Leske \& Budrich: 239-262.

Dommermuth, Lars; Hohmann-Marriott, Bryndl; Lappegård, Trude 2017: Gender equality in the family and childbearing. In: Journal of Family Issues 38,13: 1803-1824 [doi: 10.1177/0192513X15590686].

Durand, John 1948: The labor force in the United States, 1890-1940. New York: Social Science Research Council.

Durand, John 1968: The labor force in economic development. Princeton, NJ: Princeton University Press.

Engelhardt, Henriette; Kögel, Tomas; Prskawetz, Alexia 2004: Fertility and women's employment reconsidered: A macro-level time-series analysis for developed countries, 1960-2000. In: Population Studies 58,1: 109-120 [doi: 10.1080/0032472032000167715].

England, Paula 2010: The gender revolution: Uneven and stalled. In: Gender and Society 24,2: 149-166 [doi: 10.1177/0891243210361475].

Esping-Andersen, Gøsta; Billari, Francesco C. 2015: Re-theorizing family demographics. In: Population and Development Review 41,1: 1-31 [doi: 10.1111/j.17284457.2015.00024.x].

Evertsson, Marie 2014: Gender ideology and the sharing of housework and child care in Sweden. In: Journal of Family Issues, 35,7: 927-949 [doi: 10.1177/0192513X14522239]. 
Fiori, Francesca 2011: Do childcare arrangements make the difference? A multilevel approach to the intention of having a second child in Italy. In: Population, Space, and Place, 17,5: 567-596 [doi: 10.1002/psp.567].

Frejka, Tomas 2004: The 'curiously high' fertility of the USA. In: Population Studies 58,1: 88-92.

Frejka, Tomas 2011: The role of contemporary childbearing postponement and recuperation in shaping period fertility trends. In: Comparative Population Studies - Zeitschrift für Bevölkerungswissenschaft 36,4: 927-958 [doi: 10.4232/10.CPoS-2011-20en].

Frejka, Tomas et al. (Eds.) 2008: Childbearing Trends and Policies in Europe. In: Demographic Research, Special collection 7: 1-1178.

Frejka, Tomas; Goldscheider, Frances; Lappegård, Trude 2016a: The second half of the gender revolution and fertility. Paper presented at the 2016 PAA Annual Meeting. Boston.

Frejka, Tomas; Goldscheider, Frances; Lappegård, Trude 2016b: The gender revolution and fertility. Paper presented at the $\mathbf{2 0 1 6}$ meetings of the European Population Conference, Mainz, Germany.

Gauthier, Anne 2010: Comparative family policy database, Version 3 [computer file]. Netherlands Interdisciplinary Demographic Institute \& Max Planck Institute for Demographic Research (distributors) [http://www.demogr.mpg.de/cgi-bin/databases/FamPolDB/index.plx, 13.07.2018].

Goldin, Claudia 1990: Understanding the gender gap: An economic history of american women. New York: Oxford University Press.

Goldin, Claudia 2006: The quiet revolution that transformed women's employment, education, and family. In: American Economic Review 96,2: 1-21 [doi: 10.1257/000282806777212350].

Goldscheider, Frances; Bernhardt, Eva; Lappegård, Trude 2015: The gender revolution: A framework for understanding changing family and demographic behavior. In: Population and Development Review 41,2: 207-239 [doi: 10.1111/j.1728-4457.2015.00045.x].

Goldscheider, Frances; Bernhardt, Eva; Brandén Maria 2013: Domestic gender equality and childbearing in Sweden. In: Demographic Research 29,40: 1097-1126 [doi: 10.4054/DemRes.2013.29.40].

Goldscheider, Frances; Oláh, Livia; Puur Allan 2010: Reconciling studies of men's gender attitudes and fertility: Response to Westoff and Higgins. In: Demographic Research 22,8: 189-198 [doi: 10.4054/DemRes.2010.22.8].

Greulich, Angela; Thévenon, Olivier; Guergoat-Lariviere, Mathilde 2016: Securing women's employment: A fertility booster in European countries? CES Working Paper 24, Centre d'Economie de la Sorbonne, Paris.

Grunow, Daniela; Evertsson, Marie (Eds.) 2016: Couples' transitions to parenthood: Analysing gender and work in Europe. Cheltenham, UK: Edward Elgar Publishing, LTD.

Hochschild, Arlie; Machung, Anne 1989: The second shift: Working parents and the revolution at home. New York: Penguin Books.

Hofferth, Sandra; Goldscheider, Frances 2015: Fatherhood. In: Wright, James D. (editorin-chief): International encyclopedia of the social \& behavioral sciences, 2nd edition, Vol 8. Oxford: Elsevier: 840-843.

Hook, Jennifer 2006: Care in context: Men's unpaid work in 20 countries, 1965-2003. In: American Sociological Review 71,4: 639-660 [http://www.jstor.org/stable/30039013, 06.09.2018] 
HFD (Human Fertility Database) 2018: Max Planck Institute for Demographic Research (Germany) and Vienna Institute of Demography (Austria) [http://www.humanfertility. org, 06.09.2018].

ILO (International Labour Office) $1960 \mathrm{ff}$ : Yearbook of labour statistics. Geneva.

Kan, Man Yee; Sullivan, Oriel; Gershuny, Jonathan 2011: Gender convergence in domestic work: Discerning the effects of interactional and institutional barriers from largescale data. In: Sociology 45,2: 234-251 [doi: 10.1177/0038038510394014].

Klein, Thomas; Nauck, Bernhard 2004: Families in Germany. In: Adams, Bert; Trost, Jan (Eds.): Handbook of world families. Thousand Oaks, CA: Sage: 283-312 [doi: 10.4135/9781412975957.n13].

Lappegård, Trude 2018: Personal communication, 02.06.2018

Lesthaeghe, Ron 2010: The unfolding story of the Second Demographic Transition. In: Population and Development Review 36,2: 211-251 [doi: 10.1111/j.17284457.2010.00328.x]

Lesthaeghe, Ron; van de Kaa, Dirk 1986: Twee Demografische Transities? In: Lesthaeghe, Ron; van de Kaa, Dirk (Eds.): Bevolking: Groei en krimp. Mens en Maatschappij book supplement. Deventer: Van Loghum-Slaterus: 9-24.

Macunovich, Diane 1996: A review of recent developments in the economics of fertility. In: Menchik, Paul L. (Ed.): Household and Family Economics. New York: Kluwer Academic Publishers: 91-150.

Marini, Margaret; Shelton, Beth 1993: Measuring household work: Recent experience in the United States. In: Social Science Research 22,4: 361-382 [doi: 10.1006/ ssre.1993.1018].

Matysiak, Anna; Vignoli, Daniele 2008: Fertility and women's employment: A meta-analysis. In: European Journal of Population 24,4: 363-384.

McDonald, Peter 2000: Gender equity in theories of fertility transition. In: Population and Development Review 26,3: 427-439.

Mills, Melinda 2010: Gender roles, gender (in)equality and fertility: An empirical test of five gender equity indices. In: Canadian Studies in Population 37,3-4: 445-474 [doi: 10.25336/P61310].

Mitchell, Brian 1998: International Historical Statistics: Europe 1750-1993 (4th edition). London: Macmillan Reference LTD.

Morgan, S. Philip 2015: Variation in U.S. fertility: Low and not so low, but not lowestlow. In: Rindfuss, Ronald R.; Choe, Minja Kim (Eds): Low and lower fertility: Variations across industrialized countries. Springer: 125-141 [doi: 10.1007/978-3-319-21482-5_7].

Oláh, Livia; Bernhardt, Eva 2008: Sweden: Combining childbearing and gender equality. In: Demographic Research 19,28: 1105-1144 [doi: 10.4054/DemRes.2008.19.28].

Oppenheimer, Valerie 1970: The female labor force in the United States: Demographic and economic factors governing its growth and changing composition. In: Population Monograph Series 5. Berkeley: University of California.

Oppenheimer, Valerie 1974: The life-cycle squeeze: The interaction of men's occupational and family life cycles. In: Demography 11,2: 227-245 [doi: 10.2307/2060561].

OECD (Organization for Economic Cooperation and Development) 2010: Part-time employment, in OECD Factbook 2010: Economic, environmental and social statistics. OECD Publishing Paris [doi: 10.1787/factbook-2010-47-en].

OECD (Organization for Economic Cooperation and Development) 2016: Statistics [doi: 10.1787/data-00900-en]. 
OECD (Organization for Economic Cooperation and Development) 2018: Early childhood education and care - home [http://www.oecd.org/education/school/earlychildhoodeducationandcare.htm, 06.09.2018].

Pettit, Becky; Hook, Jennifer 2005: The structure of women's employment in comparative perspective. In: Social Forces 84,2: 779-801 [doi: 10.1353/sof.2006.0029].

Pinnelli, Antonella; Fiori, Francesca 2008: The influence of partner involvement in fatherhood and domestic tasks on mothers' fertility expectations in Italy. In: Fathering: A Journal of Theory, Research, and Practice about Men as Fathers 6,2: 169-191.

Pott-Buter, Hettie 1993: Facts and fairy tales about female labor, family and fertility. Amsterdam: Amsterdam University Press.

Presser, Harriet B. 2000: Nonstandard work schedules and marital instability. In: Journal of Marriage and Family 62,1: 93-110 [doi: 10.1111/j.1741-3737.2000.00093.x].

Puur, Allan et al. 2008: Men's childbearing desires and views of the male role in Europe at the dawn of the $21^{\text {st }}$ century. In: Demographic Research 19,56: 1883-1912 [doi: 10.4054/DemRes.2008.19.56].

Rindfuss, Ronald R.; Choe, Minja Kim (Eds.) 2015: Low and lower fertility: Variations across developed countries. Springer [doi: 10.1007/978-3-319-21482-5].

Rindfuss, Ronald R.; Choe, Minja Kim (Eds.) 2016: Low fertility, institutions, and their policies: Variations across industrialized countries. Springer [doi: 10.1007/978-3-31932997-0].

Rindfuss, Ronald R. et al. 2010: Childcare availability and fertility in Norway. In: Population and Development Review 36,4: 725-748 [doi: 10.1111/j.1728-4457.2010.00355.x]

Rønsen, Marit; Skrede, Kari 2010: Can public policies sustain fertility in the Nordic countries? Lessons from the past and questions for the future. In: Demographic Research 22,13: 321-346 [doi: 10.4054/DemRes.2010.22.13].

Rosenfeld, Rachel A. 1996: Women's work histories. In: Population and Development Review 22: 199-222 [doi: 10.2307/2808012].

Shows, Carla; Gerstel, Naomi 2008: Fathering, class, and gender: A comparison of physicians and emergency medical technicians. In: Gender and Society 23,2: 161-187 [doi: 10.1177/0891243209333872].

Sobotka, Tomáš; Beaujouan, Éva 2014: Two is best? The persistence of a two-child family ideal in Europe. In: Population and Development Review 40,3: 391-419 [doi: 10.1111/j.1728-4457.2014.00691.x].

Sobotka, Tomáš et al. 2011a: Postponement and recuperation in cohort fertility: Austria, Germany and Switzerland in a European Context. In: Comparative Population Studies - Zeitschrift für Bevölkerungswissenschaft 36,2-3: 417-452 [doi: 10.4232/10.CPoS2011-10en].

Sobotka, Tomáš; Skirbekk, Vegard; Philipov, Dimiter 2011b: Economic recession and fertility in the developed world. A literature review. In: Population and Development Review 37,2: 267-306 [doi: 10.1111/j.1728-4457.2011.00411.x].

Spain, Daphne; Bianchi, Suzanne 1996: Balancing act: Motherhood, marriage, and employment among american women. New York: The Russell Sage Foundation.

Stycos, James; Weller, Robert 1967: Female working roles and fertility. In: Demography 4,1: 210-217 [doi: 10.2307/2060362]. 
Stanfors, Maria; Goldscheider, Frances 2017: The forest and the trees: Industrialization, demographic change, and the ongoing gender revolution in Sweden and the United States, 1870-2010. In: Demographic Research 36,6: 173-226 [doi: 10.4054/DemRes.2017.36.6].

Sullivan, Orie/ 2010: Changing differences by educational attainment in fathers' domestic labour and child care. In: Sociology 44,4: 716-733 [doi: 10.1177/0038038510369351].

Thévenon, Olivier; Gauthier, Anne H. 2011: Family policies in developed countries: a "fertility-booster" with side-effects. In: Community, Work \& Family 14,2: 197-216 [doi: 10.1080/13668803.2011.571400].

Toulemon, Laurent; Pailhé, Ariane; Rossier, Clémentine 2008: France: High and stable fertility. In: Demographic Research 19,16: 503-555 [doi: 10.4054/DemRes.2008.19.16].

Waite, Linda; Stolzenberg, Rafe 1976: Intended childbearing and labor force participation of young women: Insights from nonrecursive models. In: American Sociological Review 41,2: 235-252 [doi: 10.2307/2094471].

Westoff, Charles; Higgins, Jenny 2009: Relationships between men's gender attitudes and fertility: Response to Puur, et al.'s “Men's Childbearing Desires and Views of the Male Role in Europe at the Dawn of the $21^{\text {st }}$ Century". In: Demographic Research 21,3: 65-74 [doi: 10.4054/DemRes.2009.21.3].

World Bank Databank 2016: [http://databank.worldbank.org/, 10.09.2018].

Dr. Tomas Frejka ( $₫)$. Independent Researcher. USA. E-mail: tfrejka@aol.com.

Prof. Dr. Frances Goldscheider. University of Maryland, Brown University. Maryland, USA. E-mail: frances_goldscheider@brown.edu URL: https://wWw.popcenter.umd.edu/mprc-associates/fgoldsch

Prof. Dr. Trude Lappegård. University of Oslo, Department of Sociology and Human Geography. Oslo, Norway. E-mail: trude.lappegard@sosgeo.uio.no URL: https://www.sv.uio.no/iss/english/people/aca/trudelap/

Authors appear in alphabetical order 


\section{Comparative Population Studies}

WWW.comparativepopulationstudies.de

ISSN: 1869-8980 (Print) - 1869-8999 (Internet)

\section{Published by}

Prof. Dr. Norbert F. Schneider

Federal Institute for Population Research D-65180 Wiesbaden / Germany

\section{(cc) BY-SA}

2018

\section{Managing Editor}

Dr. Katrin Schiefer

\section{Copy Editor}

Dr. Evelyn Grünheid

Dr. Katrin Schiefer

\section{Editorial Assistant}

Beatriz Feiler-Fuchs

Wiebke Hamann

\section{Layout \\ Beatriz Feiler-Fuchs \\ E-mail:cpos@bib.bund.de}

\section{Scientific Advisory Board}

Karsten Hank (Cologne)

Michaela Kreyenfeld (Berlin)

Marc Luy (Vienna)

Peter Preisendörfer (Mainz)

Nikola Sander (Wiesbaden)

Zsolt Spéder (Budapest)

Rainer Wehrhahn (Kiel)

\section{Board of Reviewers}

Martin Abraham (Erlangen)

Laura Bernardi (Lausanne)

Hansjörg Bucher (Bonn)

Claudia Diehl (Konstanz)

Andreas Diekmann (Zurich)

Gabriele Doblhammer-Reiter (Rostock)

Jürgen Dorbritz (Wiesbaden)

Anette Eva Fasang (Berlin)

E.-Jürgen Flöthmann (Bielefeld)

Alexia Fürnkranz-Prskawetz (Vienna)

Beat Fux (Salzburg)

Joshua Goldstein (Berkeley)

Sonja Haug (Regensburg)

Hill Kulu (Liverpool)

Aart C. Liefbroer (The Hague)

Kurt Lüscher (Konstanz)

Emma Lundholm (Umeå)

Nadja Milewski (Rostock)

Dimiter Philipov (Vienna)

Roland Rau (Rostock)

Tomáš Sobotka (Vienna)

Jeroen Spijker (Barcelona)

Olivier Thévenon (Paris)

Helga de Valk (Brussels)

Heike Trappe (Rostock)

Michael Wagner (Cologne) 